\title{
Psychological and Physiological Indices Analysis Among Athletes of Different Specializations at the Stages of Overcoming Age Related and Career Crises of Sports Activity
}

\author{
Kuznetsov A.S. \\ University of Management "TISBI" \\ Naberezhnye Chelny, Russia \\ kuznetsov-as@mail.ru
}

\author{
Usmanova E.N. \\ Sports school of the Olympic Reserve "Vityaz named after \\ M.Sh. Bibishey \\ Naberezhnye Chelny, Russia \\ evgeniya-usmanova@mail.ru
}

\author{
Kolomytseva O.V. \\ NaberezhnyeChelny State Pedagogical University \\ NaberezhnyeChelny, Russia \\ oksavicol@ rambler.ru
}

\begin{abstract}
Age related and career crises of sports activity take place on the background of inner conceptual personality's contradictions [6]. At the same time, the conditions of sports competition place demands on functional abilities of an organism and emotional sphere of athletes, in particular on specific forms of aggression demonstration, so called "sports anger". It is directed, on the one hand, toward self-overcoming, the desired results achievement, own personal bounds defense, on the other hand on motivational mindset activation to achieve socially important success. In struggle for sports reserve preservation and at all transient stages of sports career the training process starts to be considered from the position of a resource and individual-differentiated approaches $[1,7,8]$ in the format of psychological-pedagogical support.
\end{abstract}

Keywords-athletes; psychological-pedagogical support; agerelated crisis; sports career; burnout; bioimpedance content of body mass; internality; aggression; motivation; needs; factorial analysis.

\section{INTRODUCTION}

Athlete's personality formation in modern society happens in terms of hard demands of adaptation to different social groups (school collective, sports society) and is connected with different crisis periods overcoming, both in sports career and in life in general. Being expressed at behavioral level, psychic innovations of a young athlete show mastered models of behavior and created mechanisms of psychological defense in his leading activity and during interaction with society. At the same time these periods of life are the most sensitive for active cell mass gathering (till 58\%) during the leading physical qualities development and an individual style of sports activity formation, social and emotional intellect development, which provide behavior self- regulation skill development, professional and moral selfdetermination of an athlete $[2,6]$.

Searching for the interconnections of athletes' psychological-physiological indices, which form the factors, which reflect general state of the sampling at different transient stages of sports career and show the existence of favorable tendencies of age related and career crises of sports life successful overcoming, conditioned the aim of the presented research.

\section{RESEARCH METHODOLOGY}

The research was realized on the basis of the following scientific theses and the results of our previous research works:

1) successful overcoming age-related and career crises should be accompanied by physical, spiritual and intellectual spheres of athletes' personality development, including social and emotional intellect $[6,8,9]$; somatic health preservation for successful sports potential realization; 2) an optimal ratio of athletes' body weight components helps to provide not only special working capacity increase and preservation (sports fitness), but also form necessary psycho-emotional resource state during the desired weight category gaining [2,5];3)material of our previous publication of descriptive statistics according to this sampling of athletes [3].

The main research methods were the following: scientific-methodical literature analysis, bioimpedance body weight content analysis, psychological diagnostics of needmotivational, emotional, personal spheres (motivation to achieve success and failures avoidance, the degree of the main personality's needs satisfaction, "burnout syndrome”,Buss- 
Durkey Inventory, the level of subjective control), stating experiment, method of mathematical statistics (factorial analysis). The research was realized on the sampling of 74 students from sports school of the Olympic reserve. The participants of the experiment: 19 arm-wrestlers, 18 swimmers, 37 representatives of different kinds of wrestling (Greco-Roman wrestling, belt wrestling, koresh), who train at the training stage and the stage of sports improvement. The age range of the respondents was 14-25 years-old, taking the period of 4 age-related crises and 3 crises-transfers of sports career [6]. Gender and age content of the sampling is presented in Table 1.

TABLE I. GENDER AND AGE CONTENT OF THE SAMPLING (N=74)

\begin{tabular}{|c|c|c|c|c|}
\hline \multirow{2}{*}{ Gender } & \multicolumn{4}{|c|}{ Age } \\
\cline { 2 - 5 } & $14-15$ & $16-17$ & $18-20$ & $21-25$ \\
\hline Female, people & 4 & 5 & 3 & 2 \\
\hline Male, people & 31 & 16 & 7 & 6 \\
\hline
\end{tabular}

\section{RESULTS}

Because of insignificant difference of the average psychological-physiological indices according to two samplings 14-17 and 18-25 years-old [3], for specific interconnections setting between 27 variables from the selected parameters according to 7 mentioned above methodologies, we used factorial analysis for the whole sampling $(n=74)$. Factorial analysis helped to reveal factors, which describe the sampling of athletes for 70\%. As the statistical base of analysis we studied the following indices: motivation for success achievement $\left(x_{1}\right)$, motivation for failure savoidance $\left(x_{2}\right)$, material needs $\left(x_{3}\right)$, need for safety $\left(x_{4}\right)$, social needs $\left(x_{5}\right)$, need for recognition $\left(x_{6}\right)$, need for selfactualization $\left(x_{7}\right)$, generalinternality $\left(x_{8}\right)$, internality of achievements $\left(x_{9}\right)$, internality of failures $\left(x_{10}\right)$, internality of family relations $\left(x_{11}\right)$, internality ofproductive relations $\left(x_{12}\right)$, internality of interpersonal relations $\left(x_{13}\right)$, internality of health /diseases $\left(x_{14}\right), \quad$ physical aggression $\left(x_{15}\right)$, verbalaggression $\left(x_{16}\right)$, indirect $\operatorname{aggression}\left(x_{17}\right)$, negativism $\left(x_{18}\right)$, irritation $\left(x_{19}\right), \quad \operatorname{suspicion}\left(x_{20}\right)$, offense $\left(x_{21}\right), \quad \operatorname{guilt}\left(x_{22}\right), \quad$ emotionalexhaustion $\left(x_{23}\right)$, depersonalization $\left(x_{24}\right)$, personal achievements reduction $\left(x_{25}\right)$, fat component of body weight in $\%\left(x_{26}\right)$, active call mass in $\%\left(x_{27}\right)$. Own values and the accumulated dispersion of sampling are presented in table II.

TABLE II. OWN VALUES AND THE ACCUMULATED DISPERSION OF SAMPLING $(\mathrm{N}=74)$

\begin{tabular}{|c|c|c|c|c|}
\hline Factor & Eigenvalue & \% Total & Cumulative & Cumulative \\
\hline 1 & 5,380155 & 19,92650 & 5,38016 & 19,92650 \\
\hline 2 & 2,860831 & 10,59567 & 8,24099 & 30,52217 \\
\hline 3 & 2,338459 & 8,66096 & 10,57944 & 39,18313 \\
\hline 4 & 1,718623 & 6,36527 & 12,29807 & 45,54840 \\
\hline 5 & 1,610509 & 5,96485 & 13,90858 & 51,51325 \\
\hline 6 & 1,472731 & 5,45456 & 15,38131 & 56,96781 \\
\hline 7 & 1,366511 & 5,06115 & 16,74782 & 62,02896 \\
\hline 8 & 1,171552 & 4,33908 & 17,91937 & 66,36804 \\
\hline 9 & 1,066857 & 3,95132 & 18,98623 & 70,31936 \\
\hline
\end{tabular}

As a result of the factorial analysis use 5 main factors were defined, which for $52 \%$ describe this sampling, and 4 factors, which describe it totally for $18 \%$. The factors interconnection with the variables is presented in table III.

TABLEIII. THE FACTORS INTERCONNECTION WITH THE

\begin{tabular}{|c|c|c|c|c|}
\hline \multicolumn{5}{|c|}{ VARIABLES } \\
\hline № & Factors & Variables & $\begin{array}{c}\text { Values } \\
\text { of } \\
\text { factorial } \\
\text { loads }\end{array}$ & $\begin{array}{l}\text { General } \\
\text { part, } \%\end{array}$ \\
\hline \multirow[t]{8}{*}{$\mathrm{I}$} & \multirow[t]{8}{*}{$\begin{array}{c}\text { "Passive } \\
\text { aggression" }\end{array}$} & $\begin{array}{l}\text { 1. Motivation for failures } \\
\text { avoidance }\end{array}$ & $-\mathbf{0 , 5 5 5 7}$ & \multirow{8}{*}{$20 \%$} \\
\hline & & 2. Physical aggression & 0,7401 & \\
\hline & & 3. Verbal aggression & 0,7972 & \\
\hline & & 4. Indirect aggression & 0,6323 & \\
\hline & & 5. Negativism & 0,7525 & \\
\hline & & 6. Irritation & 0,6830 & \\
\hline & & 7. Emotionalexhaustion & 0,5956 & \\
\hline & & 8. Depersonalization & 0,6809 & \\
\hline \multirow[t]{6}{*}{ II } & \multirow{6}{*}{$\begin{array}{l}\text { "Self- } \\
\text { control" }\end{array}$} & 1. General internality & 0,8312 & \multirow{6}{*}{$11 \%$} \\
\hline & & $\begin{array}{l}\text { 2. Internality of } \\
\text { achievements }\end{array}$ & 0,6941 & \\
\hline & & 3. Internality of failures & 0,7573 & \\
\hline & & $\begin{array}{l}\text { 4. Internality of } \\
\text { productive relations }\end{array}$ & 0,6478 & \\
\hline & & $\begin{array}{l}\text { 5. Internality of } \\
\text { interpersonalrelations }\end{array}$ & 0,6177 & \\
\hline & & 6. Offence & $-0,5194$ & \\
\hline \multirow[t]{5}{*}{ III } & \multirow{5}{*}{$\begin{array}{c}\text { "Demands based } \\
\text { essence of } \\
\text { achievements" }\end{array}$} & $\begin{array}{l}\text { 1. Motivation for } \\
\text { success achievement }\end{array}$ & 0,5383 & \multirow{5}{*}{$9 \%$} \\
\hline & & 2. Material needs & $-0,4943$ & \\
\hline & & 3. Need for safety & $-0,6576$ & \\
\hline & & $\begin{array}{l}\text { 4. Need for self- } \\
\text { actualization }\end{array}$ & 0,7363 & \\
\hline & & $\begin{array}{l}\text { 5. Personal achievements } \\
\text { reduction }\end{array}$ & 0,4741 & \\
\hline \multirow[t]{3}{*}{ IV } & \multirow[t]{3}{*}{ "Corporality" } & $\begin{array}{l}\text { 1. Fat components of } \\
\text { body mass }\end{array}$ & $-0,7219$ & \multirow{3}{*}{$6 \%$} \\
\hline & & 2. Active cell mass & 0,5693 & \\
\hline & & 3. Needforrecognition & 0,4597 & \\
\hline \multirow[t]{2}{*}{$\mathrm{V}$} & \multirow[t]{2}{*}{ "Sociability" } & 1. Social need & 0,7957 & \multirow{2}{*}{$6 \%$} \\
\hline & & 2. Offence & 0,4651 & \\
\hline \multirow[t]{2}{*}{$\begin{array}{l}\text { VI- } \\
\text { IX }\end{array}$} & "others" & & $0,2-0,4$ & $18 \%$ \\
\hline & Total & & & $70 \%$ \\
\hline
\end{tabular}

\section{DISCUSSION}

"Passive aggression" factor (20\%) reflects specific behavioral strategy of this sampling of athletes in terms of aggression demonstration forms (physical, verbal, indirect) as an instrumental means for aim achievement, and for hostile self-actualization (negativism, irritation). It was stated that the higher the motivation level of failures avoidance is, the lower is the level of aggression and the components of emotional burnout, connected with communication. If this motivation is low, aggression level is high and there is the tendency of emotional burnout according to the components of "emotional exhaustion", "depersonalization".

"Self-control" factor (11\%) includes 5 variables of 8 scales of internality and the form of aggressiveness "offence" 
[7] Tolochek V.A. Styles of activity: resource approach. Moscow: Publishing house of Institute of psychology of the Russian Academy of Science. 2015, 366.

[8] Usmanova E.N. Psychological-pedagogical support of 14-16 year-old football players sports training on the basis of individual-differentiated approach. Candidate's thesis. Naberezhnye Chelny. 2014, 23.

[9] Yasyukova L.A., Belavina O.V. Social intellect of children and teenagers. Moscow: Institute of psychology of the Russian Academy of Science. 2017, 181
"Corporality" and "Sociability" factors 6\% prove typical for teen-age and youth urgent questions of outer attractiveness and successful socialization in "own" environment. At the same time unsatisfied social need is accompanied by offence, which positively correlates with externality and the prevalence of muscle mass over the fat tissue in the body positively correlates with the need for recognition.

\section{CONCLUSIONS}

Psychological-physiological indices analysis revealed specific interconnections, which form factor structure of the semantic space for psychological-pedagogical service activity, concerning sports reserves preservation at all transient stages of sports career.

The research results formed the base for the thesis and program of psychological-pedagogical service creation, which supports sports training in sports school of the Olympic reserve. The service activity is oriented toward the following:

- on the other hand, toward the need for development and self-actualization realization, motivation support for success achievement, emotional intellect and communicative skills, internal type of control, an optimal ratio of active cell and fat body mass development;

on the other hand, toward emotional burnout prevention and level indices of motivational tendency increase for failures avoidance, as the reflection of unfavorable tendencies for successful age-related and career crises overcoming in sports life of young athletes.

\section{References}

[1] Gorskaya G.B., Somviz Z.R. Psychological resources of long-term psychic loads overcoming at different stages of athletes' professional career in team kinds of sport. Physical culture and sport - science and practice. 2018, 3, pp. 88-93.

[2] Kolomytseva O.V. Possibilities of bioimpedant body content analysis use in the practice of wrestling coach. Innovative technologies in training athletes in sports wrestling: materials of the I All-Russian scientificpractical conference, October, 29-30, 2014. Naberezhnye Chelny: Publishing house of Naberezhnye Chelny branch of Povilzhskaya State Academy of Physical Culture, Sport and Tourism. 2014, pp. 124-126.

[3] Kuznetsov A.S., Usmanova E.N., Kolomytseva O.V. Psychologicalphysiological indices study among athletes of different specializations at the stages of sports career crises overcoming. Pedagogico-psychological and medico-biological problems of physical culture and sport. 2019, 14(2), pp. 89-96. DOI: 10.14526/2070-4798-2019-14-2-89-96.

[4] Nikolaev D.V., Smirnov A.V., Bobrinskaya I.G., Rudnev S.G. Bioimpedance analysis of body content. Moscow: Science(Nuka). 2009, 392.

[5] Nikolaev D.V., Shchelykalina S.P. Lectures on bioimpedance analysis of a person's body content. Moscow: RIO TNIIOIZ MZ RF. 2016, 152.

[6] Stambulova N.B. Psychology of sports career: manual. Saint-Petersburg: Career center. 1999, 368. 